INTERNATIONAL JOURNAL OF MULTidisciplinARY RESEARCH AND ANALYSis

ISSN(print): 2643-9840, ISSN(online): 2643-9875

Volume 04 Issue 04 April 2021

DOI: 10.47191/ijmra/v4-i4-11, Impact Factor: 6.072

Page No.- $435-437$

\title{
Assessment of Ecoturistic Opportunities of Shakhrisabz District
}

\section{G'olib Nortoshevich Aliqulov' ${ }^{1}$, Fazilat Ibrokhim qizi Muzropova ${ }^{2}$, Ravshan Abdurazakovich Eshonkulov ${ }^{3}$, PhD}

${ }^{1}$ Candidate agricultural sciences, Associate professor, Head of Department "Geodesy, cadastry and land management", Karshi Engineering-Economic Institute, Uzbekistan

${ }^{2}$ Assistant, Lecturer, Department of "Geodesy, cadastry and land management",Karshi Engineering-Economic Institute, Uzbekistan ${ }^{3}$ Head of Department "Ecology and labour protection", Karshi Engineering-Economic Institute, Uzbekistan

ABSTRACT: Ecotourism and its development depends not only on the socio-economic conditions of the study area, but also on the natural conditions of the area, the presence of ecotourism sites and their geographical location. Because the characteristics of natural conditions allow us to determine the ecotourism potential of the region and what species can be developed.

KEYWORDS: Ecotourism, Kashkadarya region, Shakhrisabz district, sustainable development, Miraki, Gissar Mountains, Tamerlane cave, landscape.

\section{INTRODUCTION}

Tourism activity in our country has been considered at the level of the main state policy since the early days of independence. In this regard, the Decree of the President of the Republic of Uzbekistan dated February 3, 2018 No PF-5326 "On additional organizational measures to create favorable conditions for the development of tourism potential of the Republic of Uzbekistan", PQ-3514 "On measures to accelerate the development of domestic tourism" In order to ensure the implementation of the decisions and orders of the relevant ministries and organizations, all the necessary organizational and legal mechanisms for the development of the industry have been created. Today, the necessary conditions have been created in our country for the development of tourism and its rise to new heights, to make our country one of the world's tourist centers. In the case of Kashkadarya region alone, the number of companies and organizations engaged in tourism in 2019 was 7, and in 2019 they served 11,873 visitors (Figure1). The number of tourists from foreign countries amounted to 361,738 . (30.7\%).

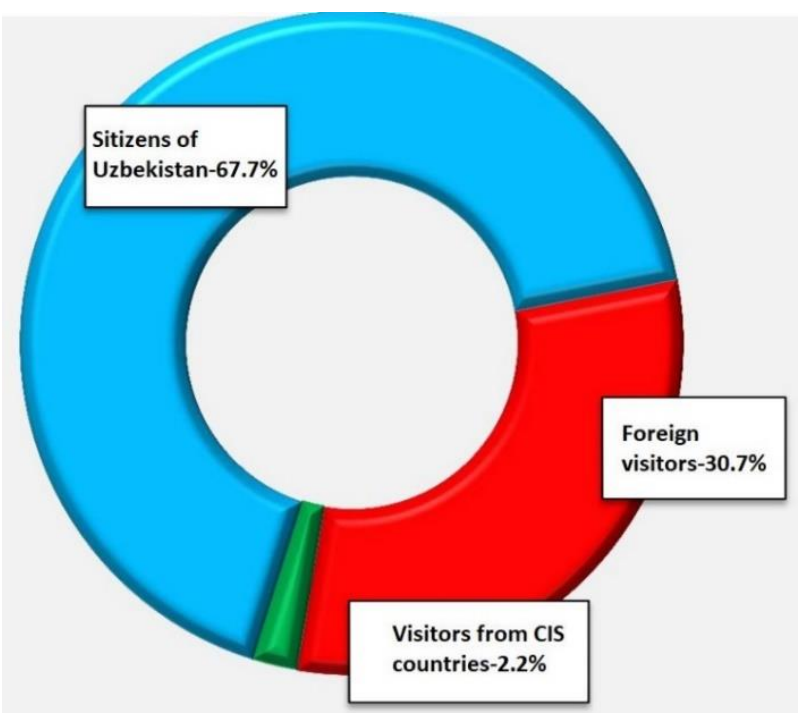

Figure 1. The share of visitors served in Kashkadarya region in 2019 among the citizens of the CIS, foreign and Kashkadarya region, in percent (source: https://www.qashstat.uz/images/tahliliy/turizm/turizm19.pdf) 


\section{Assessment of Ecoturistic Opportunities of Shakhrisabz District}

\section{LITERATURE REVIEW AND METHODOLOGY}

The tourism industry is a sector of the economy that, along with the accumulation of large investments and resources, performs the spiritual and educational functions necessary for an independent state and society. Through ecotourism, foreign visitors get an idea of the rich and unique nature of Uzbekistan, while citizens of Uzbekistan get acquainted with their homeland. It is sufficient to say that they have the opportunity to form a sense of national pleasure and pride in their homeland (Aliqulov 2018, Tukhliyev 2006).

Ecotourism is a network of scientific directions and practices. In addition, it performs various social, economic, political, environmental functions (Alexandrova, 2008). Revealing the scientific and theoretical foundations of ecotourism and its natural geographical aspects, identifying and analyzing the ecotourism potential of the nature of Shakhrisabz district, showing ways to use them wisely are among the current issues (Aliqulov \& Eshonkulov, 2021; Khoshimov Murodjon, 2009).

The main purpose of this study is to reveal the development of the scientific basis of eco-tourism in Shakhrisabz district of Kashkadarya region. To achieve this goal requires the following tasks:

- identification of the object and subject of ecotourism;

- classification of ecotourism in the territory of Shakhrisabz district;

- $\quad$ to reveal the natural geographical aspects of ecotourism;

- identification of important factors that characterize the ecotourism potential of nature (landscapes) of Shakhrisabz district and identify indicators that characterize them;

ecotouristic zoning of Shakhrisabz district;

Problems of sustainable development are especially important for nature reserves, which have unique natural sites and wonders related to tourism. The income of the majority of the population living in such areas is formed by the high influx of tourists. This situation is more typical for mountainous and foothill areas (Aliqulov, 2018). Shakhrisabz district has such opportunities.

The district was founded on September 29, 1926. It is bordered by Kitab district in the north, Tajikistan and Surkhandarya region in the east, Yakkabag and Kamashi districts in the south, and Chirakchi district in the west. The area is 1.70 thousand km². There is a city (Shakhrisabz) in the district: 1 town (Miraki), 12 rural communities (Dukchi, Kunchikar, Muminabad, Namaton, Aksuv, Todamaydon, China, Shakarteri, Shamaton, Uzbekistan, Kutchi, Hisorak). The center is the city of Shakhrisabz. The district is located in the north-eastern part of Kashkadarya region, in the foothills of the Gissar Mountains. The western part of the district consists of an open oasis - a plain adjoining the Karshi desert. The Aksu, Kashkadarya, Tankhozdarya, Kyzyldarya, Tamshush, and Miraki rivers flowing from the mountains formed ravines. The climate is continental. The average annual temperature is $14.7^{\circ}$. The average January temperature is $0.8^{\circ}$, and the lowest is $-26^{\circ}$. The district has a high ecotourism potential. For example, Gilan and Kul villages, Varganza and Hazrati Bashir villages, Amir Temur cave, Sarchashma and Suvtushar cultural resorts. In addition, the Gissar State Reserve, located in the district, is an important ecotourism site. It is a state reserve located to the west of the Gissar mountain range (in the mountainous areas of Yakkabag and Shakhrisabz districts) and was established on the basis of the Kyzylsuv (1975) and Miraki (1976) reserves (1983). The area is 80,986.1 ha, of which 12,203 ha are forests, 2,745 ha are grasslands and 17 ha are water basins. Created to preserve natural landscape complexes and ecosystems of the Gissar Range.

The natural objects of the reserve are unique. Here is one of the deepest caves in Central Asia - the famous cave of the Tamerlane (Amir Temur Kuragani). At an altitude of more than 2,900 meters, the settlement consists of two caves that are almost 1,000 meters long. The caves here have high stalactite groves and a beautiful underground lake fed by unique springs. Notable tourist attractions include Hazrat Sultan Holy Mountain, fossilized dinosaur footprints, Suvtushar waterfalls, Kizilshavar Karst Plateau, Khojakarshavar High Mountain Plateau, Janka High Mountain Lake, Kalasay Gorge, Zarmas Gorge, Seversev Glacier, Gilan, Zarmas and Lake sermanzara mountain villages, Kyzylgaz summer pastures can be found.

There is another miracle in the nature corner of the Miraki branch of the reserve - the famous Suvtushar waterfall. It is the longest and wettest waterfall in the country. In May-July, the 84-meter-high waterfall releases 5-6 cubic meters of water per second. The particles formed in this process are scattered for 250-300 meters, during strong winds up to 500-600 meters and create a wonderful microclimate. Considered a beautiful gift of nature, this waterfall is reminiscent of a beautiful girl, with fragments of water falling from a huge boulder 2,100 meters above sea level. The water in the strong current bubbles and turns white. That is why the locals also call him "Sutshari" (milk ball). Therefore, the study of natural and geographical features and landscape structure of this area is of great practical importance in the rational, efficient and economical use of natural resources.

The purpose of the development of ecotourism in Shakhrisabz district is:

demonstration of ecotourism potential, natural potential and resources of Shakhrisabz in the market of tourist services of the Republic;

- encourage scientific research aimed at more efficient use of ecotourism resources and opportunities of the region, especially nature and geosystem's 


\section{Assessment of Ecoturistic Opportunities of Shakhrisabz District}

- increasing the role and share of ecotourism in the development of tourism;

- rapid improvement of the quality of ecotourism services and rapid increase in the volume of ecotourism services in the tourist activities introduced in Shakhrisabz;

- creation of scientific, innovative and methodical developments aimed at the development of ecotourism in the future;

Another important point to note is that the majority of the local population is uninformed of the historical monuments, shrines and health resorts in their area. In this regard, it is necessary to further expand the awareness of the tourist potential of the district, to provide a series of materials in the media. The presence of local residents and foreign tourists can be further enhanced by organizing various entertainment events, festivals and campaigns at the existing historical monuments, shrines and health resorts in the region.

\section{CONCLUSION}

In summary, the article focuses on the scientific solution of tourism problems, focusing on the classification of ecotourism on the example of Shakhrisabz district, ecotourism opportunities of geographical complexes, the separation of ecotourism areas and the organization of routes in them. In the process of solving this ecotourism problem, the following interrelated scientific results can be achieved, namely:

Geographical complexes (landscapes) are the main object of assessment in determining the ecotourism potential of the region, which objectively reflects the natural potential of the region. Therefore, we need to consider the identification, mapping and comprehensive study of geocomplexes as the first step in identifying and assessing the ecotourism potential of the region.

The unique natural conditions of the region and the diversity of ecotourism opportunities make ecotourism zoning of its territory.

Nowadays, most of the income abroad (Canada, Australia, Germany, several African countries, Nepal, etc.) comes through tourism. In order to increase the amount of foreign currency in Uzbekistan, including in Shakhrisabz district, it is necessary to develop tourism, especially ecotourism.

\section{REFERENCES}

1) Tukhliev N. (2006). Ecological tourism: Экологический туризм: essence, tendency and development strategy. Tashkent. 416 p. (in uzbek).

2) Alexandrova A.Yu. (2008). Geography Tourism. Textbook. - M.: KNORUS, 592 p. (in Russian).

3) Shamuratova N., Azimova D. Ecotourism opportunities of Tashkent region. UzA, 2020.(in uzbek).

4) Aliqulov, G. (2018). Prospects for increasing the efficiency of farming in the foothills. Journal of Innovation technologies. Volume 1, p. 36-38. (in uzbek).

5) Aliqulov, G., \& Eshonkulov, R. (2021). The Effect Of Soil-Climate On The Drain Productivity Of Peas Grown In Dryland. The American Journal of Interdisciplinary Innovations and Research, 03(01), 82-91.

6) Khoshimov Murodjon. (2009). Ekological tourism of Uzbekistan. 216 p. (in uzbek). 